\title{
From stress due to E-HRM practices towards the stress due to digital communication: conceptual framework of the problematic
}

\author{
Mrs. SALMOUN Khaoula, Pr. CHAFIK Khalid
}

\author{
Abdelmalek Essaadi University \\ Center for Doctoral Studies: Law, Economics and Management \\ Doctoral Training: Economics, Management \\ National School of Commerce and Management of Tangier
}

\begin{abstract}
:
This research was carried out in 2 phases: Firstly, the objective of the research was to examine the sources and consequences of stress when using E-HRM. Secondly, after the exploratory study, the objective of the research shifted towards the analysis of the stress due to digital communication given the requirements of the studied field. In the first phase, we highlighted the effect of stress induced by E-HRM on staff satisfaction and productivity, by proposing a conceptual model that explains this relationship (conceptual model of stress induced by E - HRM), in order to answer the following research question: How can EHRM-induced stress affect staff satisfaction and productivity? This model is based on the transactional theory of stress (Lazarus, 1966) and the 2011 Tarafdar model. Subsequently, we tried to identify the EHRM stressors and to ensure the feasibility of the proposed model, through an exploratory study with 3 companies operating in aeronautics and automotive sector. Following this study, we moved to the second phase by redirecting the theme to internal digital communication, and reformulating the problematic to be: How the stress induced by digital communication can influence staff productivity? The next planning step will be a continuation of the exploratory study to refine the final model, and subsequently the empirical treatment that will examine the hypotheses from the collected data. During this stage, we will start from a theory and hypotheses, towards a quantitative study, which will help us answer our problematic and confirm or invalidate our hypotheses.
\end{abstract}

Key words: digital communication, stress, productivity

\section{Introduction:}

The technical advances that the world has known since 1970 - the rise of Internet and the advent of WEB 2.0 in particular, have led to a much richer and more complex information environment that has given rise to several forms of communication: collaborative platforms, intranet, chats, cell phones, email, instant messaging, etc. This type of communication has been considered as a source of stress by several studies, among others YIN 2014 study that stated that there is a positive correlation between mobile techno stress and satisfaction, which interconnect with our research question: How the stress induced by digital communication can influence staff productivity?

As the theme has evolved and has been developed in two phases, our article will follow accordingly with respect to this sequence, and will be structured in two sections, one for each phase.

\section{Theoretical background and development of the research model}

\section{Section 1: Theoretical background and model of the first phase}

E-HRM has been defined by (Ruel 2004) as a method of implementing various HRM strategies, policies and practices within organizations through conscious and direct support and use of WEB-based technology channels. 
Most studies consider that E-HRM ensures efficiency (Lepak and Snell, 2007, Ruel et al, 2007), however, empirical researches on technology (IT) consequences revealed contradictory findings on almost every dimension of supposed IT consequences, which prompted us to think has sought and examined the relationship between stress and E-HRM and if this relationship has effects on satisfaction and productivity.

\section{Theory and Reference Model:}

Transaction stress theory: describes the phenomenon of stress as a particular transaction between the person and the environment in which the situation is assessed by the individual as taxing or exceeding his resources and threatening his well-being. (Lazarus and Folkman, 1984).

\section{The Tarafdar 2011 model: The Technostress Phenomenon}

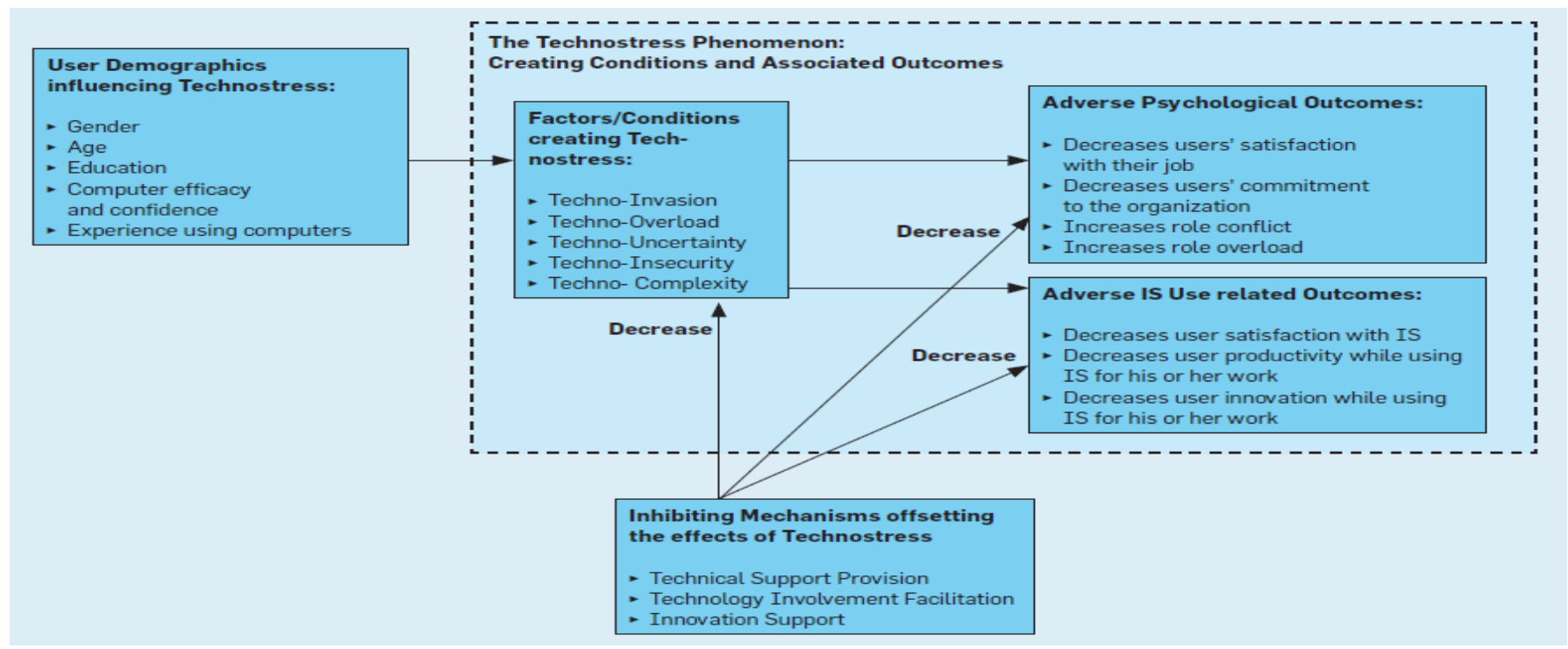

The proposed research model:

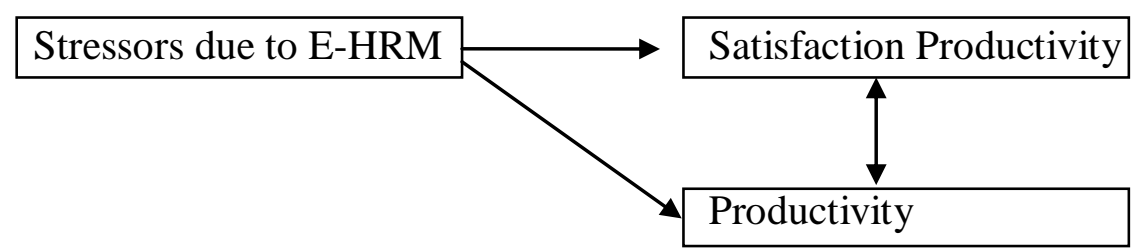

In order to define and fix stressors related to E-HRM and to refine this model, we started with an inventory and an analysis of previous studies that addressed E-HRM with the same perspective of our theme, and subsequently an investigation study was conducted in the form of interviews with three HR managers.

\section{Review of previous studies}

\begin{tabular}{|c|c|}
\hline Studied articles & Conclusions \\
\hline $\begin{array}{l}\text { Analyzing the impact of HRIS implementations on HR } \\
\text { personnel's job satisfaction and turnover intention } \\
\text { (Christian 2012) }\end{array}$ & \multirow{5}{*}{$\begin{array}{l}\text { 1. The TAM model is not valid for our study } \\
\text { since the analyzed phase by the two models } \\
\text { is not the same. } \\
\text { 2. The problematic chosen for the theme is } \\
\text { poorly set, since it comprises two major } \\
\text { questions: On one hand, the relationship } \\
\text { between stress and E-HRM, which is still an } \\
\text { unclear relationship and requires further } \\
\text { research to be established. On the other } \\
\text { hand, the relationship between stress (due to } \\
\text { E-HRM) and satisfaction and productivity. }\end{array}$} \\
\hline $\begin{array}{l}\text { Satisfaction towards EHRM in government organization } \\
\text { of MALYSIA : a proposed model based on field theory } \\
\text { (Hadziroh 2013) }\end{array}$ & \\
\hline $\begin{array}{l}\text { The unexpected side of relational e-HRM : developing } \\
\text { trust in the HR department (Bissola 2014) }\end{array}$ & \\
\hline $\begin{array}{l}\text { Determinants of attitude towards E-HRM: an empirical } \\
\text { study among HR professionals (yusliza 2012) }\end{array}$ & \\
\hline $\begin{array}{l}\text { E-HRM: A proposed model based on technology } \\
\text { acceptance model (Yusliza 2010) }\end{array}$ & \\
\hline
\end{tabular}


Results of the exploratory study:

\begin{tabular}{|c|c|c|}
\hline Samples & Methodology followed & Conclusions \\
\hline $\begin{array}{l}\text { Case 1: HR } \\
\text { manager of } \\
\text { company Alpha } \\
\text { operating in the } \\
\text { aeronautics } \\
\text { industry with a } \\
\text { staff of } 150 \\
\text { employees; } \\
\text { Case 2: HR } \\
\text { manager of } \\
\text { company Beta } \\
\text { operating in the } \\
\text { automotive sector } \\
\text { with a staff of } 500 \\
\text { employees; } \\
\text { Case 3: HR } \\
\text { manager of } \\
\text { company Gamma } \\
\text { operating in the } \\
\text { automotive sector } \\
\text { with a staff of } \\
\text { more than } 5000 \\
\text { employees. }\end{array}$ & $\begin{array}{l}\text { Our exploratory study was carried } \\
\text { out according to the qualitative } \\
\text { method with a hypothetico- } \\
\text { inductive approach. } \\
\text { The qualitative data collection tool } \\
\text { chosen is: the semi-directive } \\
\text { interview with an interview guide. } \\
\text { We began our study with } 3 \\
\text { interviews lasting between } 20 \\
\text { minutes to } 60 \text { minutes. Interviews } \\
\text { took place face to face by note- } \\
\text { taking. } \\
\text { Data analysis: } \\
\text { Case-by-case analysis: We will } \\
\text { transpose the maintenance corpus } \\
\text { into a number of content- } \\
\text { representative themes. We then } \\
\text { search for matches with the } \\
\text { predefined variables. } \\
\text { Themes transversal analysis: the } \\
\text { comparative study or cross-analysis } \\
\text { which allows to generalize the } \\
\text { observations through several } \\
\text { representations of these themes }\end{array}$ & $\begin{array}{l}\text { Moroccan companies are still lagging behind } \\
\text { regarding the use of E-HRM tools, despite the } \\
\text { fact that the chosen samples include companies } \\
\text { that belong to the main sectors of Morocco. } \\
\text { Not all E-HRM tools create stress. On the } \\
\text { contrary, there are those that contribute to the } \\
\text { well-being of users. } \\
\text { Stress outcomes are not all negative, users can } \\
\text { experience a stress level that helps them } \\
\text { improve. } \\
\text { There are variables that can be moderating this } \\
\text { relationship stress/satisfaction. } \\
\text { The tools that end up generating stress among } \\
\text { users are those whose characteristics create } \\
\text { stress environment such as dispersion, } \\
\text { insecurity, overload, etc. These tools consist } \\
\text { mainly of communication ones. } \\
\text { Communication, that is considered to be stress- } \\
\text { generating, can be either internal or external, } \\
\text { linked to HR service- e.g. intranet, or not-e.g. } \\
\text { emails, telephone, etc, institutional or domestic. } \\
\text { It concerns the entire company staff and not } \\
\text { only those of HR department. } \\
\text { Hence, samples must include different profiles } \\
\text { to multiply and vary analysis visions. }\end{array}$ \\
\hline
\end{tabular}

These conclusions led us to consider redirecting the study towards a more relevant phenomenon in Moroccan context, one that is abundant and commonly experienced by target population (managers). In light of the above findings, the research theme takes on a new meaning by changing E-HRM to digital communication (e-mail, instant messaging, calls).

Section 2: Theoretical background and model of the second phase

Digital communication and stress

\begin{tabular}{|l|l|}
\hline \multicolumn{1}{|c|}{ Stress stimulus } & \multicolumn{1}{c|}{ Authors } \\
\hline Overload or techno-overload & $\begin{array}{l}\text { Cindy Felio 2011, kalika and al 2014, Tarafdar 2007 and al, } \\
\text { Ragunathan 2008 et al, Pengzhen Yin and al 2014, Debra 2011 and } \\
\text { al. }\end{array}$ \\
\hline Reachability & Cindy Felio 2011, kalika and al 2014. \\
\hline Dispersion or interruption & Cindy Felio 2011, Datchary 2004, thomas 2004, Dabbish 2004. \\
\hline Sense of urgency, instantaneity & Cindy Felio 2011, Kalika and al 2014. \\
\hline Techno-insecurity & $\begin{array}{l}\text { Pengzhen Yin and al 2014, Ragunathan and al 2008, Tarafdar and al } \\
\text { 2011 }\end{array}$ \\
\hline
\end{tabular}




\begin{tabular}{|l|l|}
\hline \multicolumn{1}{|c|}{ Studied articles } & \multicolumn{1}{|c|}{ Conclusions } \\
\hline $\begin{array}{l}\text { Click-to-Click: Creativity and } \\
\text { Rationalization in Corporate } \\
\text { Intranets Uses }\end{array}$ & $\begin{array}{l}\text { The existing scientific literature dealing with the relationship } \\
\text { between productivity and digital communication focuses mainly on } \\
\text { the productivity of communication channels, while leaving the } \\
\text { notion of stress out of their analysis of this relationship. }\end{array}$ \\
\cline { 1 - 2 } $\begin{array}{l}\text { Effect of online social networking on } \\
\text { employee productivity }\end{array}$ & $\begin{array}{l}\text { Other studies that shed light on effects of stress on productivity, } \\
\text { generally restrict the scope of their work on a single communication } \\
\text { item: e.g. e-mails. }\end{array}$ \\
\cline { 1 - 2 } $\begin{array}{l}\text { Social Media and Productivity in the } \\
\text { Constraints }\end{array}$ & $\begin{array}{l}\text { Most of studies on technology highlight a very interesting idea } \\
\text { regarding users perception that can be a source of either positive or } \\
\text { negative appropriation, and therefore the outcome will be positively } \\
\text { or negatively impacted. }\end{array}$ \\
\cline { 1 - 2 } $\begin{array}{l}\text { Workplace impact of social } \\
\text { networking }\end{array}$ & $\begin{array}{l}\text { Productivity is generally measured by means of the amount of } \\
\text { worked hours. }\end{array}$ \\
\hline
\end{tabular}

\section{The proposed new research model:}

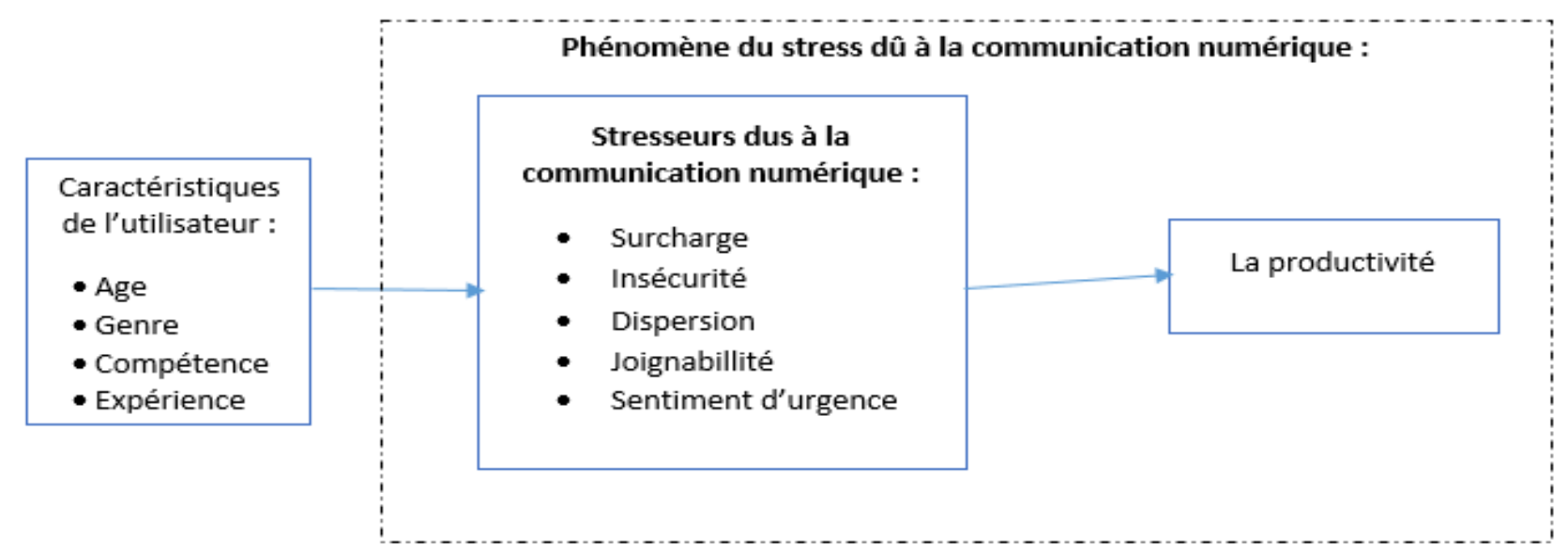

The objective of the conceptual model of stress induced by digital communication is to analyze the influence of this stress on the productivity of the staff. Therefore, this model is based on the transactional stress theory (Lazarus, 1966) and the 2011 Tarafdar model (technostress phenomenon).

\section{Conclusion:}

Initially, the research aim was to analyze the effects of stress induced by E-HRM on satisfaction and productivity of staff, however, after the exploratory study findings, research focus has been reoriented towards digital communication. Therefore, the next stage of the work at hand will be a continuity of the exploratory study to refine the final model, and subsequently an empirical treatment and examination of field collected data to verify hypotheses validity.

During this stage, we will start from a theory and hypotheses, to end up with a quantitative study that will help us answer our problematic.

\section{Références}

[1] A. Ferreira, T. du Plessis, Effect of online social networking on employee productivity, 2009. 
[2] Benjamin B. Aguenza, Amer Hani Al-Kassem, Ahmad Puad Mat Som, Social Media and Productivity in the Workplace: Challenges and Constraints, Interdisciplinary Journal of Research in Business, 2012.

[3] Christian Maier, $\underline{S}$ Laumer, A Eckhardt, $T$ Weitzel, Analysing the impact of HRIS implémentations on HR personnel's job satisfaction and turnover intention, 2012.

[4] Caroline Datchary, «Prendre au sérieux la question de la dispersion au travail. Le cas d'une agence de création d'événements », Réseaux (no 125), p. 175-192. DOI 10.3917/res.125.0175, 2004/3.

[5] George Halkos and DimitriosBousinakis, The effect of stress and satisfaction on productivity, International Journal of Productivity and Performance Management, 2009.

[6] Laura A. Dabbish, Robert E. Kraut, Email overload at work: An analysis of factors associated with email strain, 2006.

[7] Laura Dabbish, Robert E. Kraut, Controlling Interruptions: Awareness Displays and Social Motivation for Coordination, Proceedings of the 2004 ACM conference on computer supported cooperative work pages 182-191, 2004.

[8] La Rupelle Géraldine et al., « Messagerie électronique, facteur de stress dans le cadre de la relation managériale », Revue de gestion des ressources humaines, /1 N 91, p. 13-28, 2014.

[9] Marisa Salanova, Susana Llorens, and Eva Cifre, The dark side of technologies: Technostress among users of information and communication technologies, INTERNATIONAL JOURNAL OF PSYCHOLOGY, 1-15, iFirst, 2012.

[10] MY. Yusliza, Hadziroh Ibrahim, Satisfaction towards e-hrm in government organisations of malaysia: a proposed model based on field theory, Proceeding of the International Conference on Social Science Research, ICSSR 2013 (e-ISBN 978-967- 11768-1-8), 2013.

[11] MY Yuslizaa, T Ramayahba, Determinants of attitude towards E-HRM: an empirical study among HR professionals, 2012.

[12] MonideepaTarafdar, QiangTu, T.S. Ragu-Nathan, Crossing to the dark side: Examining creators, outcomes, and inhibitors of technostress, RIT Scholar Works, 2011.

[13] MonideepaTarafdar, QiangTu, T.S. Ragu-Nathan, 2007, The impact of technostress on role stress and productivity, Journal of Management Information System, 2011.

[14] Ragu-Nathan. T, MonideepaTarafdar, Bhanu Ragu-Nathan, , The Consequences of technostress for end users in organizations: Conceptual development and empirical validation, 2008.

[15] Renato Cudicio, Serge Proulx, La messagerie instantanée en entreprise: Accélérateur ou frein à la productivité?, Groupe de recherche sur les usages et cultures médiatiques, Université du Québec à Montréal,June 2014.

[16] Serge Proulx, Penser les usages des technologies de l'information et de la communication aujourd'hui : enjeux - modèles - tendances, in Lise Vieira et Nathalie Pinède, éds, Enjeux et usages des TIC : aspects sociaux et culturels, Tome 1, Presses universitaires de Bordeaux,Bordeaux, p. 7 20, 2005.

[17] Stephen R. Barley, Debra E. Meyerson, Stine Grodal, E-mail as a Source and Symbol of Stress, Organization Science Vol. 22, No. 4, pp. 887-906, 2011.

[18] Sylvie ROLLAND, Sébastien TRAN, La dimension organisationnelle dans la productivité des tic : Le cas de la messagerie électronique dans le secteur des service, WorkingPaper IMRI 2007/02.

[19] WadiTahri, Bernard Fallery« L'usage de la messagerie électronique : une méta-analyse des travaux francophones sur la période 2000-2008 », Management \& Avenir (n 34), p. 183-199, 2010/4. 